\title{
Characterization of Titanium Oxide Nanoparticles Obtained by Hydrolysis Reaction of Ethylene Glycol Solution of Alkoxide
}

\author{
Naofumi Uekawa, Naoya Endo, Keisuke Ishii, Takashi Kojima, and Kazuyuki Kakegawa \\ Graduate School of Engineering, Chiba University, 1-33 Yayoi-cho, Inage-ku, Chiba-shi 263-8522, Japan \\ Correspondence should be addressed to Naofumi Uekawa, uekawa@faculty.chiba-u.jp
}

Received 1 December 2011; Revised 15 February 2012; Accepted 29 February 2012

Academic Editor: Wegdan Ramadan

Copyright ( $) 2012$ Naofumi Uekawa et al. This is an open access article distributed under the Creative Commons Attribution License, which permits unrestricted use, distribution, and reproduction in any medium, provided the original work is properly cited.

\begin{abstract}
Transparent and stable sols of titanium oxide nanoparticles were obtained by heating a mixture of ethylene glycol solution of titanium tetraisopropoxide (TIP) and a $\mathrm{NH}_{3}$ aqueous solution at $368 \mathrm{~K}$ for $24 \mathrm{~h}$. The concentration of $\mathrm{NH}_{3}$ aqueous solution affected the structure of the obtained titanium oxide nanoparticles. For $\mathrm{NH}_{3}$ aqueous solution concentrations higher than $0.2 \mathrm{~mol} / \mathrm{L}$, a mixture of anatase $\mathrm{TiO}_{2}$ nanoparticles and layered titanic acid nanoparticles was obtained. The obtained sol was very stable without formation of aggregated precipitates and gels. Coordination of ethylene glycol to $\mathrm{Ti}^{4+}$ ions inhibited the rapid hydrolysis reaction and aggregation of the obtained nanoparticles. The obtained titanium oxide nanoparticles had a large specific surface area: larger than $350 \mathrm{~m}^{2} / \mathrm{g}$. The obtained titanium oxide nanoparticles showed an enhanced adsorption towards the cationic dye molecules. The selective adsorption corresponded to presence of layered titanic acid on the obtained anatase $\mathrm{TiO}_{2}$ nanoparticles.
\end{abstract}

\section{Introduction}

Titanium dioxide $\left(\mathrm{TiO}_{2}\right.$ titania) is an n-type oxide semiconductor that shows photocatalytic activity and photoconductivity $[1,2]$. Several various applications of $\mathrm{TiO}_{2}$ particles have been studied in recent years, as photocatalysts and to solar cells, UV-shielding materials and electric devices [3-6]. For these applications, development of a simple synthesis method to obtain $\mathrm{TiO}_{2}$ nanoparticles with highly homogeneous dispersion has been required $[7,8]$. $\mathrm{TiO}_{2}$ nanoparticles are also useful in many important applications for improving environmental problems $[9,10]$. These nanoparticles can be used for formation of $\mathrm{TiO}_{2}$ thin films with optical transparency and photocatalyst activity. Furthermore, surface characteristics of $\mathrm{TiO}_{2}$ nanoparticles strongly affect the application area of $\mathrm{TiO}_{2}$ nanoparticles. For example, Grätzel developed photoelectrochemical systems with dye-sensitized anatase $\mathrm{TiO}_{2}$ semiconductor electrodes $[11,12]$. The characteristics of these solar cells depend on adsorption interaction between dye molecules and $\mathrm{TiO}_{2}$ nanoparticle surface. Therefore, it is also important to control molecular adsorption properties of $\mathrm{TiO}_{2}$ nanoparticles.
Rath et al. prepared size-controlled $\mathrm{TiO}_{2}$ nanoparticles in reverse micelles using a surfactant Aerosol-OT (AOT) [13]. Zaki et al. obtained anatase $\mathrm{TiO}_{2}$ nanoparticles through hydrolysis of ethanol solution of titanium tetraisopropoxide by adding nitric acid [14]. They examined an adsorption of amine molecules to investigate the surface adsorption sites. Nakayama and Hyashi prepared stable sols of $\mathrm{TiO}_{2}$ with surface modification of carboxylic acid and amine [15]. Some reports have also described methods for preparation of $\mathrm{TiO}_{2}$ nanoparticles and stable sols using peroxotitanic acid as a precursor [16].

This study describes examination of a novel preparation method of titanium oxide nanoparticles and their stable sols through hydrolysis reaction of an ethylene glycol solution of titanium alkoxide with $\mathrm{NH}_{3}$ aqueous solution. Ethylene glycol easily coordinates to $\mathrm{Ti}^{4+}$ ions and controls the hydrolysis reaction $[17,18]$. Furthermore, $\mathrm{NH}_{3}$ molecules also strongly coordinate to the $\mathrm{Ti}^{4+}$ ions. It is expected that restricting rapid hydrolysis reaction enables the production of titanium oxide nanoparticles without aggregation. Furthermore, surface characteristics of the titanium oxide nanoparticles were examined by measuring adsorption isotherms of cationic and anionic dye molecules. 


\section{Experiments}

2.1. Preparation of Titanium Oxide Nanoparticles and Their Sols. The titanium oxide nanoparticles were prepared as follows. The $1 \mathrm{~mol} / \mathrm{L}$ of $\mathrm{NH}_{3}$ aqueous solution was added to the $50 \mathrm{~mL}$ of ethylene glycol solution $(0.1 \mathrm{~mol} / \mathrm{L})$ of titanium tetraisopropoxide (TIP). The total volume was adjusted to $100 \mathrm{~mL}$. Under these circumstances no precipitate was observed, although an opaque solution was obtained. This solution was heated at $368 \mathrm{~K}$ for $24 \mathrm{~h}$ in a closed glass vessel, and a stable sol was obtained without precipitation. All chemicals used in this preparation were of reagent grade (Wako Pure Chemical Industries Ltd.). To control the particle size and surface properties of the obtained titanium oxide nanoparticles, the same synthetic process was also conducted using the $\mathrm{NH}_{3}$ (aq) with other concentrations. The concentrations were in the range of $0.1 \mathrm{~mol} / \mathrm{L}-1 \mathrm{~mol} / \mathrm{L}$. Hereinafter, this concentration will be designated as $\left[\mathrm{NH}_{3}\right]$.

To separate the obtained particles from the sol, $50 \mathrm{~mL}$ of the obtained sol was poured into a cellulose tube for dialysis, and the cellulose tube was soaked in $500 \mathrm{~mL}$ of $\mathrm{H}_{2} \mathrm{O}$ for $3 \mathrm{~h}$ at room temperature. The $500 \mathrm{~mL}$ of $\mathrm{H}_{2} \mathrm{O}$ was exchanged five times. Finally, the sol in the cellulose tube was dried at $348 \mathrm{~K}$ for $12 \mathrm{~h}$.

Anatase $\mathrm{TiO}_{2}$ particles were also prepared using a simple hydrolysis reaction between Ti alkoxide and $\mathrm{H}_{2} \mathrm{O}$. The $\mathrm{H}_{2} \mathrm{O}$ was added to $0.01 \mathrm{~mol}$ of TIP. Then the total volume was adjusted to $100 \mathrm{~mL}$. The mixed solution of TIP and $\mathrm{H}_{2} \mathrm{O}$ was kept in a closed glass beaker and heated at $368 \mathrm{~K}$ for $24 \mathrm{~h}$. White precipitate was obtained using the hydrolysis reaction. The precipitate was separated by centrifugation at $3000 \mathrm{rpm}$ for $5 \mathrm{~min}$. The obtained precipitate was dried at $348 \mathrm{~K}$ for $24 \mathrm{~h}$.

2.2. Characterization. The structure of the obtained particles was characterized using X-ray diffraction (XRD) $(\mathrm{Cu} \mathrm{K} \alpha$ 40 kV, 100 mA, MXP-18; Bruker AXS Co., Ltd.). The particle shape was observed using field emission scanning electron microscopy (FE-SEM: JSM-6330; JEOL) after osmium coating, which is one of the electroconductive film formation methods for electron microscope observation. It is the method for depositing osmium metal thin film on the sample surface by DC glow discharge in osmium oxide gas. The ultraviolet-visible (UV-VIS) spectra of the sols and the solutions were measured using quartz cell (UV2000; Hitachi Ltd.) with wavelengths of $300-800 \mathrm{~nm}$, and the optical path length of the cell was $1 \mathrm{~cm}$. Thermogravimetric analysis and differential thermal analysis (TG-DTA) were measured in the air with the flow rate $=100 \mathrm{~mL} / \mathrm{min}$. Weight of the used samples was $10 \mathrm{mg}$, and the rate of elevating temperature was $10 \mathrm{~K} / \mathrm{min}$. The upper limit of the measuring temperature was $1073 \mathrm{~K}$. The $\mathrm{N}_{2}$ adsorption isotherms of the obtained powders were measured at $77 \mathrm{~K}$ by using the volumetric method (BELSORP-max, BEL Japan, Inc.) after pretreatment at $383 \mathrm{~K}$ in $1 \mathrm{mPa}$ for $1 \mathrm{~h}$. The used sample weight was ca. $0.1 \mathrm{~g}$.

2.3. Dye Adsorption Measurement. Dye adsorption isotherms of the titanium oxide nanoparticles were measured as described below. First, $50 \mathrm{~mL}$ of methylene blue aqueous solutions was prepared and adjusted to the following concentrations: $1 \times 10^{-4} \mathrm{~mol} / \mathrm{L}, 2 \times 10^{-4} \mathrm{~mol} / \mathrm{L}, 3 \times 10^{-4} \mathrm{~mol} / \mathrm{L}$, $4 \times 10^{-4} \mathrm{~mol} / \mathrm{L}, 6 \times 10^{-4} \mathrm{~mol} / \mathrm{L}$, and $8 \times 10^{-4} \mathrm{~mol} / \mathrm{L} .0 .05 \mathrm{~g}$ of the titanium oxide powder was added to $50 \mathrm{~mL}$ of each of the methylene blue aqueous solution. The $\mathrm{pH}$ values of the dye aqueous solution with dispersion of the titanium oxide powder were in the range from 6.5 to 7.5 before and after the adsorption. Each dye aqueous solution with the titanium oxide powder was stirred at $500 \mathrm{rpm}$ at $298 \mathrm{~K}$ for $24 \mathrm{~h}$ to reach the equilibrium of dye adsorption. From each solution, $3 \mathrm{~mL}$ of the methylene blue aqueous solution was separated using filtration with a $0.45 \mu \mathrm{m}$ membrane filter. The optical absorbance of the corrected methylene blue aqueous solution at $655 \mathrm{~nm}$ was measured using a UVVIS spectrometer (UV2000; Hitachi Ltd.). The methylene blue concentrations were calculated from the absorbance using a working curve. Measurements of the dye adsorption isotherm described above were also conducted using other dyes such as crystal violet, Evans blue, and eosin Y. The respective wavelengths used for estimating the dye aqueous solution concentrations of crystal violet, Evans blue, and eosin $\mathrm{Y}$ were $590 \mathrm{~nm}, 608 \mathrm{~nm}$, and $517 \mathrm{~nm}$.

\section{Results and Discussion}

3.1. Characterization of the Obtained Titanium Oxide Nanoparticles. Figure 1 portrays XRD patterns of the particles obtained by heating the mixture of ethylene glycol solution of TIP and $\mathrm{NH}_{3}$ (aq) at $368 \mathrm{~K}$ for $24 \mathrm{~h}$. The XRD peaks in Figures 1(a)-1(e), as marked with open circles, can be assigned to anatase $\mathrm{TiO}_{2}$. When the concentration of the $\mathrm{NH}_{3}$ (aq) concentration mixed with the ethylene glycol solution of TIP was $0.1 \mathrm{~mol} / \mathrm{L}$, the obtained titanium oxide was anatase $\mathrm{TiO}_{2}$ as shown in Figure 1(a). When the mixture of TIP and $\mathrm{H}_{2} \mathrm{O}$ was heated at $368 \mathrm{~K}$ for $24 \mathrm{~h}$, anatase $\mathrm{TiO}_{2}$ was also obtained as shown in Figure 1(e). In Figure 1(b), a very weak and broad peak around $2 \theta<10^{\circ}$ can be assigned to layered titanic acid structure [19]. When the $\mathrm{NH}_{3}$ (aq) concentration became higher than $0.2 \mathrm{~mol} / \mathrm{L}$, the XRD peaks shown in Figures 1(b)-1(d) can be assigned to layered titanic acid lattice and anatase $\mathrm{TiO}_{2}$. Accordingly, the $\mathrm{NH}_{3}$ (aq) concentration affected the crystal structure of the obtained particles. Furthermore, crystallite sizes were determined by using Scherrer's equation at the peak of anatase $\mathrm{TiO}_{2}(101)$ plane at $2 \theta=25.8^{\circ}$. The crystallite sizes determined from the XRD patterns of Figures $1(\mathrm{a})-1(\mathrm{e})$ were $4.68 \mathrm{~nm}, 4.60 \mathrm{~nm}$, $2.88 \mathrm{~nm}, 2.27 \mathrm{~nm}$, and $10.7 \mathrm{~nm}$, respectively. Accordingly, a decrease in crystallite size was observed with increases in the $\mathrm{NH}_{3}$ (aq) concentration. Furthermore, the crystallite size of anatase $\mathrm{TiO}_{2}$ of Figure 1(a) was smaller than that of Figure 1(e). This result means that growth of the crystallite size of the anatase $\mathrm{TiO}_{2}$ particles was restricted by coordination of the coexisted $\mathrm{NH}_{3}$ and ethylene glycol molecules in the solution.

Figure 2 shows FE-SEM images of the obtained titanium oxide particles. Figures 2(a), 2(b), and 2(c), respectively, show FE-SEM images of particles obtained using the $\mathrm{NH}_{3}$ 


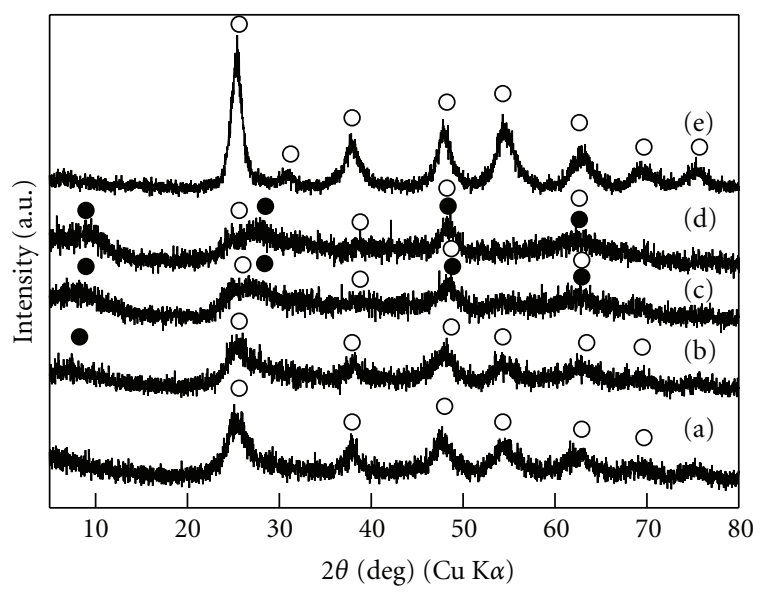

FIGURE 1: XRD patterns of the obtained particles by heating a mixture of ethylene glycol solution of TIP and $\mathrm{NH}_{3}$ (aq) at $368 \mathrm{~K}$ for $24 \mathrm{~h}$. The $\mathrm{NH}_{3}$ (aq) concentrations were (a) $0.1 \mathrm{~mol} / \mathrm{L}$, (b) $0.2 \mathrm{~mol} / \mathrm{L}$, (c) $0.5 \mathrm{~mol} / \mathrm{L}$, (d) $1 \mathrm{~mol} / \mathrm{L}$, and (e) the particles obtained by heating the mixture of TIP and $\mathrm{H}_{2} \mathrm{O}$ at $368 \mathrm{~K}$ for $24 \mathrm{~h}$. $\bigcirc$ : anatase $\mathrm{TiO}_{2}$ and $\mathrm{O}$ layered titanic acid.

(aq) at concentrations of $0.1 \mathrm{~mol} / \mathrm{L}, 0.5 \mathrm{~mol} / \mathrm{L}$, and $1 \mathrm{~mol} / \mathrm{L}$. When the $\left[\mathrm{NH}_{3}\right]$ values were $0.1 \mathrm{~mol} / \mathrm{L}, 0.5 \mathrm{~mol} / \mathrm{L}$, and $1 \mathrm{~mol} / \mathrm{L}$, the average particle sizes were $32.1 \mathrm{~nm}, 31.5 \mathrm{~nm}$, and $28.0 \mathrm{~nm}$, respectively. The particle sizes of the obtained titanium oxide particles were almost close to each other. The coordination of $\mathrm{NH}_{3}$ aqueous solution did not affect the particle size of the titanium oxide nanoparticles, although as discussed in Figure 1, the crystal structure was affected. The average particle sizes determined by FE-SEM images of the titanium oxide nanoparticles were larger than the crystallite sizes determined by using Scherrer's equation. This means that the particles observed in the FE-SEM images had aggregated structure of crystallites. Furthermore, when the $\mathrm{NH}_{3}$ (aq) concentration was more than $0.5 \mathrm{~mol} / \mathrm{L}$, the particle shape would change from spherical particles to plate particles. This will be one of the reasons of difference between the crystallite size and the average particle size.

To examine the residual organic molecules and the degree of the crystallization of the obtained nanoparticles, the TGDTA curves were measured. Figure 3(a) shows the TG-DTA curve of the nanoparticles obtained by using the $\mathrm{NH}_{3}$ (aq) $\left(\left[\mathrm{NH}_{3}\right]=0.1 \mathrm{~mol} / \mathrm{L}\right)$. The TG curve had $15.1 \%$ weight loss below $400 \mathrm{~K}$. This weight loss corresponded to desorption of adsorbed $\mathrm{H}_{2} \mathrm{O}$ on the nanoparticles. Furthermore, when the temperature was around $523 \mathrm{~K}$, a steep decrease of weight was observed. According to the DTA curve, a sharp exothermic peak also appeared around $523 \mathrm{~K}$. Therefore, the weight loss around $523 \mathrm{~K}$ corresponded to the oxidation of the TIP molecules which did not react in the hydrolysis reaction. The weight loss around this temperature was $8.1 \%$. Furthermore, a slight decrease of weight (4.82\%) occurred at temperatures of $530 \mathrm{~K}$ to $700 \mathrm{~K}$. This weight loss corresponded to dehydration of surface $\mathrm{OH}$ groups and desorption of the adsorbed ammonium ions. Figure $3(\mathrm{~b})$ shows the TG-DTA curve of the nanoparticles obtained using the $\mathrm{NH}_{3}(\mathrm{aq})\left(\left[\mathrm{NH}_{3}\right]=1 \mathrm{~mol} / \mathrm{L}\right)$. In this case, $24 \%$ of the large weight loss caused by desorption of adsorbed $\mathrm{H}_{2} \mathrm{O}$ was also observed below $400 \mathrm{~K}$. The DTA curve had an exothermic peak around $535 \mathrm{~K}$, and the temperature was close to that of Figure 4(a). Therefore, this DTA peak corresponds to the oxidation of organic molecules. The weight loss around this temperature was $2.4 \%$. This value of the weight loss in Figure 3(b) was less than that in Figure 3(a). This result means that TIP molecules in the $1 \mathrm{~mol} / \mathrm{L}$ of $\mathrm{NH}_{3}$ (aq) are more effectively hydrolyzed than those in the $1 \mathrm{~mol} / \mathrm{L}$ of $\mathrm{NH}_{3}$ (aq). Furthermore, the slight decrease in mass corresponded to desorption of ammonium ions and the surface $\mathrm{OH}$ groups, as discussed in Figure 3(a). Accordingly, the hydrolysis reaction of titanium alkoxides proceeded more effectively at higher concentrations of $\mathrm{NH}_{3}$ (aq).

3.2. Investigation of Dispersion Stability and Formation Process of Sols by Using UV-VIS Absorption Spectra Measurements. To examine dispersed state of particles in the obtained sols, UV-VIS absorption spectra were measured as presented in Figure 4. When the $\left[\mathrm{NH}_{3}\right]$ was $0.05 \mathrm{~mol} / \mathrm{L}$, the value of optical absorbance at $400 \mathrm{~nm}$ was 0.35 . In this case, the obtained solution was a slightly opaque sol. Then, the observed optical absorbance corresponded to scattering of light. Furthermore, when wavelength decreased from $400 \mathrm{~nm}$ to $320 \mathrm{~nm}$, the optical absorbance increased from 0.35 to 3.00. This increase of the optical absorbance corresponds to the electron transition between band gap of $\mathrm{TiO}_{2}$. In general, a charge transfer transition between $\mathrm{O}^{2-}$ ion and $\mathrm{Ti}^{4+}$ ion also causes optical absorption in this wavelength range [20]. Figures 4(f)-4(h) show optical absorption spectra of isopropanol solution of TIP whose concentrations were, respectively, $1 \mathrm{~mol} / \mathrm{L}, 0.1 \mathrm{~mol} / \mathrm{L}$, and $0.01 \mathrm{~mol} / \mathrm{L}$. According to Figure 4(f), the absorption edge of the charge transfer transition was around $355 \mathrm{~nm}$ when the concentration of the isopropanol solution of TIP was $1 \mathrm{~mol} / \mathrm{L}$. As shown in Figures $4(\mathrm{f})-4(\mathrm{~h})$, with decreasing the TIP concentration in the solution from $1 \mathrm{~mol} / \mathrm{L}$ to $0.01 \mathrm{~mol} / \mathrm{L}$, the wavelength of the absorption edge shifted from $355 \mathrm{~nm}$ to a shorter wavelength. Because the maximum concentration of TIP in the obtained sol was $0.05 \mathrm{~mol} / \mathrm{L}$, the absorption edge, which corresponded to the charge transfer, was expected to be less than $355 \mathrm{~nm}$. The strong absorption around $375 \mathrm{~nm}$ in Figure 4(a) accordingly corresponded to the band gap transition of electrons in $\mathrm{TiO}_{2}$. When the $\left[\mathrm{NH}_{3}\right]$ were greater than $0.1 \mathrm{~mol} / \mathrm{L}$, the optical absorbance at $400 \mathrm{~nm}$ was less than 0.05 . Therefore, the obtained sol was almost transparent for visible light, and the scattering of light by the particles in the sol was slight. Therefore, transparent and homogeneous sols without precipitate are obtainable merely by heating the mixture of ethylene glycol solution of TIP and $\mathrm{NH}_{3}$ (aq). Furthermore, the wavelength of the absorption edge decreased with the increase of the $\left[\mathrm{NH}_{3}\right]$, and the wavelengths remained longer than $360 \mathrm{~nm}$. The strong optical absorption corresponded to the band gap electron transition of $\mathrm{TiO}_{2}$ and indicated the formation of $\mathrm{TiO}_{2}$ particles in the solution during the heating process.

To examine the formation process of titanium oxide nanoparticles in the TIP solution, we examined change 


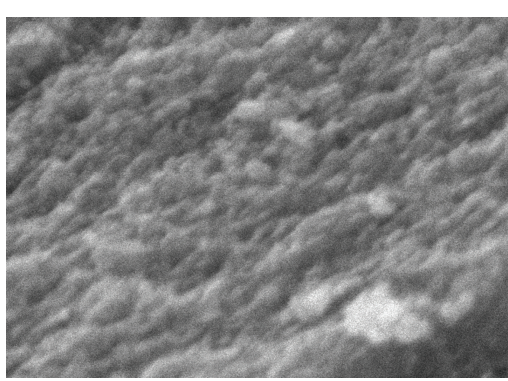

$-100 \mathrm{~nm}$

(a)

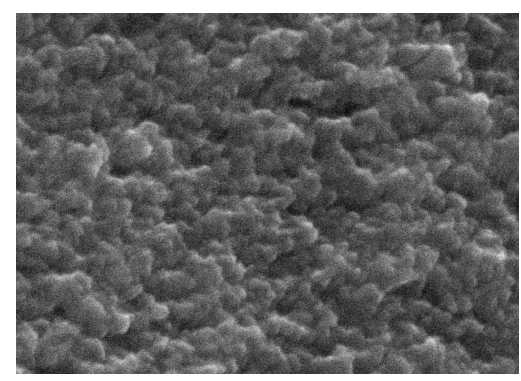

$100 \mathrm{~nm}$

(b)

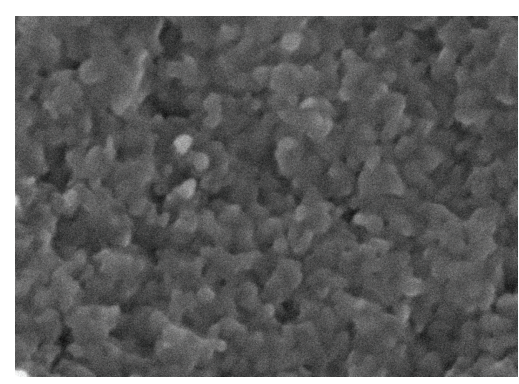

$100 \mathrm{~nm}$

(c)

Figure 2: FE-SEM images of the titanium oxide particles obtained by heating the mixture of ethylene glycol solution of $\mathrm{TIP}^{\mathrm{and}} \mathrm{NH}_{3}$ (aq) at $368 \mathrm{~K}$ for $24 \mathrm{~h}$. The $\left[\mathrm{NH}_{3}\right]$ values were (a) $0.1 \mathrm{~mol} / \mathrm{L}$, (b) $0.5 \mathrm{~mol} / \mathrm{L}$, and (c) $1 \mathrm{~mol} / \mathrm{L}$.

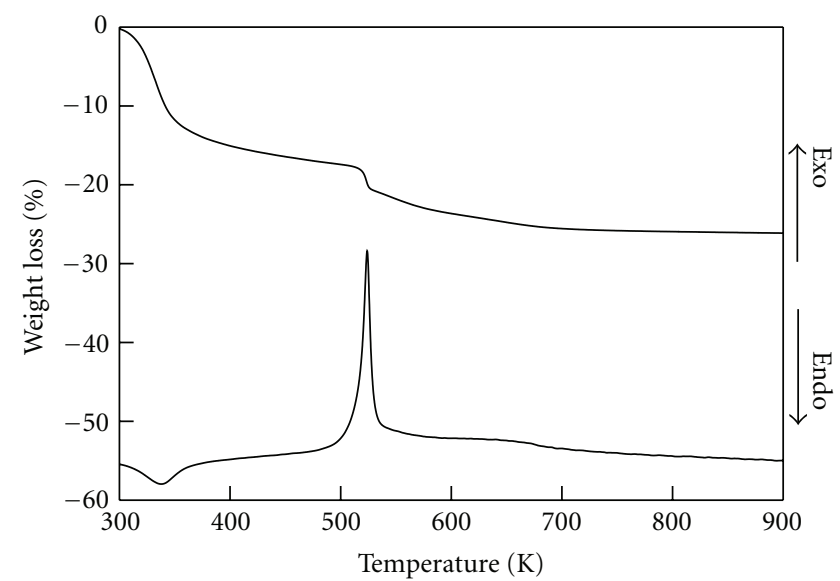

(a)

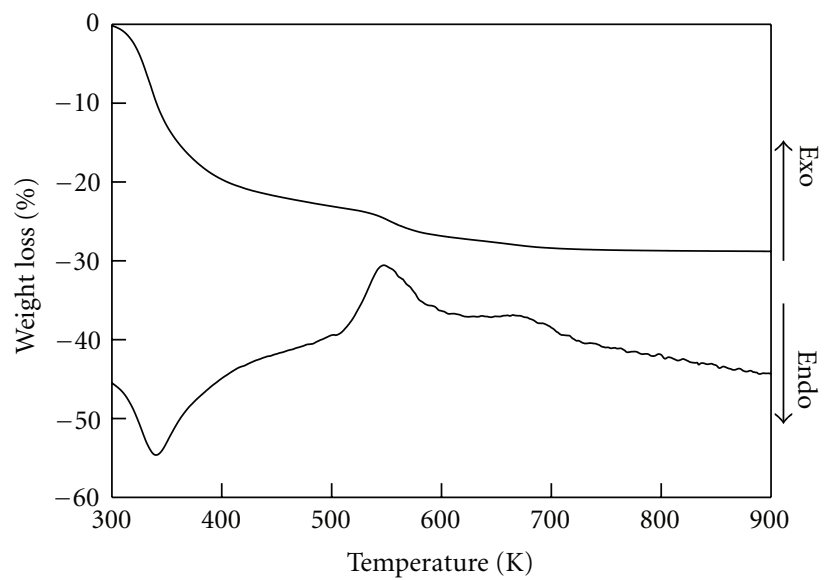

(b)

FIgURE 3: TG-DTA curves of the titanium oxide nanoparticles obtained by heating the mixture of ethylene glycol solution of $\mathrm{TIP}_{\text {and }} \mathrm{NH}_{3}$ (aq). The $\left[\mathrm{NH}_{3}\right]$ values were (a) $0.1 \mathrm{~mol} / \mathrm{L}$ and (b) $1 \mathrm{~mol} / \mathrm{L}$.

of UV-VIS absorption spectra of the solution during the heating process. Figure 5 portrays the UV-VIS absorption spectra of the sols obtained by heating the mixture of ethylene glycol solution of TIP and $\mathrm{NH}_{3}$ (aq) at $368 \mathrm{~K}$. As presented in Figure 5(a), when the heating time was $0 \mathrm{~h}$, that is, before the heat treatment, value of the optical absorbance at $400 \mathrm{~nm}$ was 0.52 . The obtained solution was an opaque sol. Then, the observed optical absorbance corresponded to scattering of light. The optical absorbance increased from 0.35 to 3.00 for wavelengths of $400-320 \mathrm{~nm}$. This spectrum resembled that portrayed in Figure 2(g). Therefore, this increase of the optical absorbance corresponds to the charge transfer transition between $\mathrm{O}^{2-}$ ion and $\mathrm{Ti}^{4+}$ ion. As presented in Figure 5(b), the optical absorbance at $400 \mathrm{~nm}$ of the solution that had been heated for $1 \mathrm{~h}$ was 0.01 . Accordingly, the obtained solution was almost transparent in the visible light wavelength range. The absorption edge was $344 \mathrm{~nm}$. When heating times were longer than $1 \mathrm{~h}$, the optical absorption at $400 \mathrm{~nm}$ remained almost 0 , which indicates that the solution was transparent and the clear sol was obtained. The absorption edge of the steep increase of absorbance shifted from $344 \mathrm{~nm}$ to $359 \mathrm{~nm}$ when the heating time increased from $0 \mathrm{~h}$ to $24 \mathrm{~h}$. This shift of the wavelength of the absorption edge indicated the formation of anatase $\mathrm{TiO}_{2}$ lattice. If the shift of the adsorption edge was caused by decrease of the concentration of TIP in the solution, the wavelength of the charge transfer absorption would shift to shorter wavelength with increase of the heating time. The band gap energy, which corresponds to the wavelength of the absorption edge, depends on the size of nanoparticles by the quantum size effect. Therefore, the shift of the absorption edge signifies formation of titanium oxide and change of its particle sizes. Accordingly, the heating of the mixture of ethylene glycol solution of TIP and $\mathrm{NH}_{3}$ (aq) at $368 \mathrm{~K}$ for more than $1 \mathrm{~h}$ was sufficient to obtain the transparent and homogeneous sol of titanium oxide nanoparticles.

3.3. Dye Adsorption Characteristics of the Titanium Oxide Nanoparticles Obtained by Hydrolysis Reaction of Ethylene Glycol Solution of TIP. To examine the surface properties of the obtained titanium oxide nanoparticles, the $\mathrm{N}_{2}$ adsorption isotherms at $77 \mathrm{~K}$ were measured, and the BET-specific surface area was estimated. Figure 6 shows $\mathrm{N}_{2}$ adsorption isotherms of the titanium oxide nanoparticles obtained with 


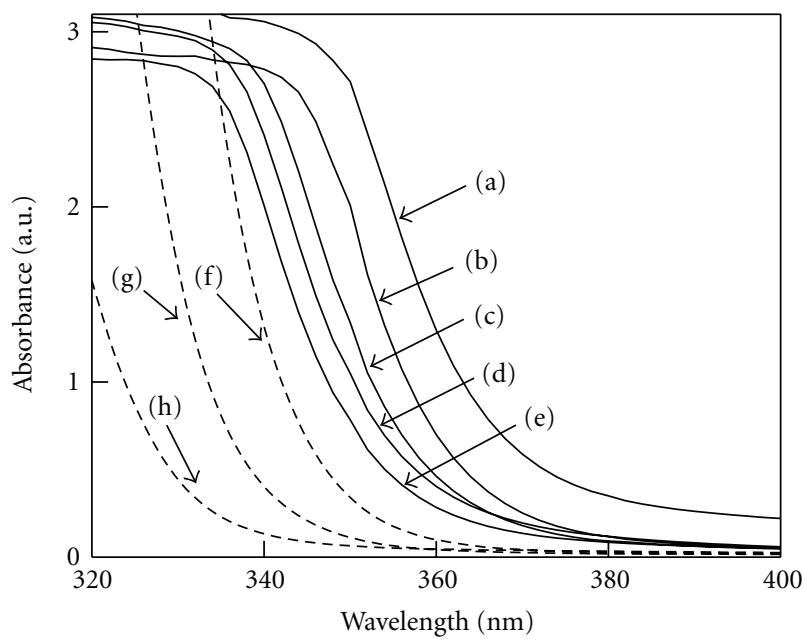

FIGURE 4: UV-VIS absorption spectra of the sols obtained by heating the mixture of ethylene glycol solution of TIP and $\mathrm{NH}_{3}$ (aq) at $368 \mathrm{~K}$ for $24 \mathrm{~h}$. The solid line shows the spectra of the obtained sols. The $\mathrm{NH}_{3}$ (aq) concentrations were (a) $0.05 \mathrm{~mol} / \mathrm{L}$, (b) $0.1 \mathrm{~mol} / \mathrm{L}$, (c) $0.2 \mathrm{~mol} / \mathrm{L}$, (d) $0.5 \mathrm{~mol} / \mathrm{L}$, and (e) $1 \mathrm{~mol} / \mathrm{L}$. The broken lines show spectra of the isopropanol solution of TIP. The TIP concentrations of the solutions were (f) $1 \mathrm{~mol} / \mathrm{L}$, (g) $0.1 \mathrm{~mol} / \mathrm{L}$, and (h) $0.01 \mathrm{~mol} / \mathrm{L}$.

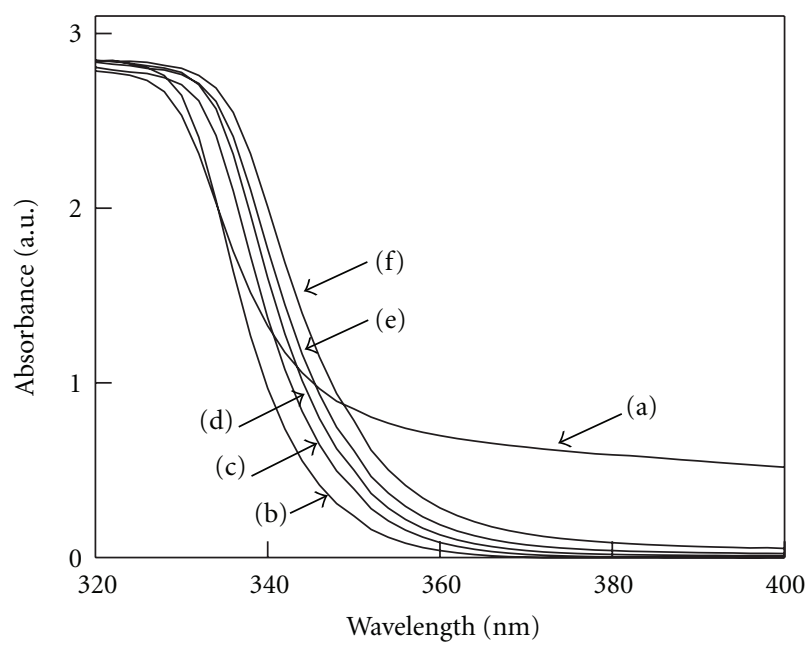

Figure 5: UV-VIS absorption spectra of the mixture of ethyleneglycol solution of TIP and $\mathrm{NH}_{3}(\mathrm{aq})\left(\left[\mathrm{NH}_{3}\right]=1 \mathrm{~mol} / \mathrm{L}\right)$. The heating temperature was $368 \mathrm{~K}$. The heating times were the following: (a) $0 \mathrm{~h}$ (before heating), (b) $1 \mathrm{~h}$, (c) $3 \mathrm{~h}$, (d) $6 \mathrm{~h}$, (e) $12 \mathrm{~h}$, and (f) $24 \mathrm{~h}$.

$0.1 \mathrm{~mol} / \mathrm{L}$ and $1 \mathrm{~mol} / \mathrm{L}$ of the $\mathrm{NH}_{3}$ (aq). Additionally, a $\mathrm{N}_{2}$ adsorption isotherm of the conventional anatase $\mathrm{TiO}_{2}$ particles obtained by heating the mixture of TIP and $\mathrm{H}_{2} \mathrm{O}$ at $368 \mathrm{~K}$ for $24 \mathrm{~h}$ is also shown in Figure 6. Both $\mathrm{N}_{2}$ adsorption isotherms obtained with the $\mathrm{NH}_{3}$ aqueous solutions belong to the type I isotherms defined by IUPAC. The $\mathrm{N}_{2}$ adsorption isotherm of the conventional anatase $\mathrm{TiO}_{2}$ particles belongs to the type IV isotherm, and the hysteresis loop can be classified to the type $\mathrm{H} 2$ [21]. The $\mathrm{N}_{2}$ adsorption isotherms of the titanium oxide nanoparticles were analyzed by using $\mathrm{BJH}$ method to estimate the average pore sizes and the total

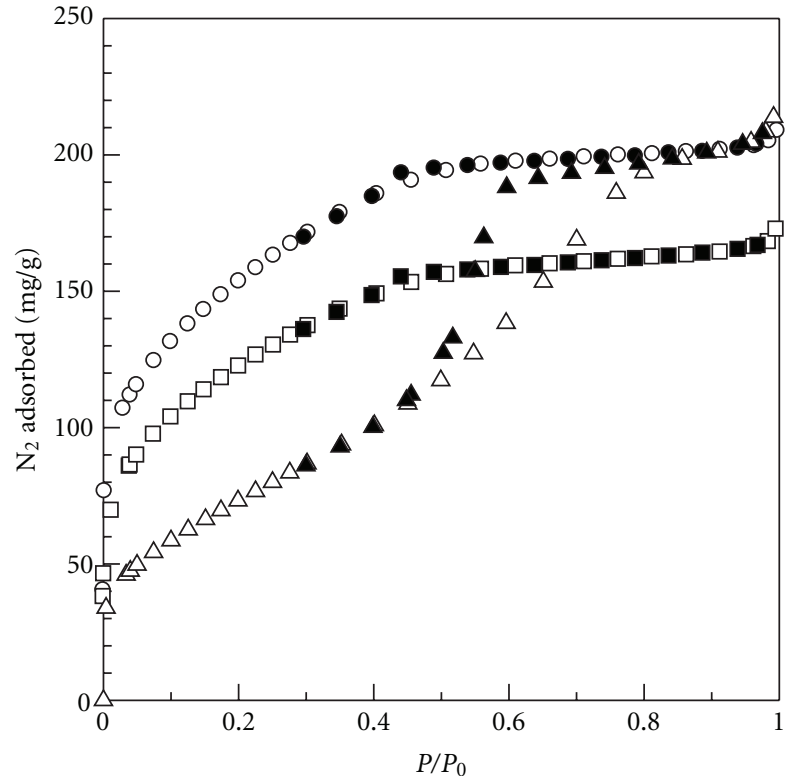

FIGURE 6: $\mathrm{N}_{2}$ adsorption isotherms of the titanium oxide nanoparticles obtained by heating the mixture of ethylene glycol solution of TIP and $\mathrm{NH}_{3}$ (aq) at $77 \mathrm{~K}$. $\bigcirc$, ๑: adsorption and desorption isotherms of $\left[\mathrm{NH}_{3}\right]=1 \mathrm{~mol} / \mathrm{L} . \square, \boldsymbol{\square}$ : adsorption and desorption isotherms of $\left[\mathrm{NH}_{3}\right]=0.1 \mathrm{~mol} / \mathrm{L} . \Delta \boldsymbol{\Delta}$ : adsorption and desorption isotherms of particles obtained by heating the mixture of TIP and $\mathrm{H}_{2} \mathrm{O}$ at $368 \mathrm{~K}$ for $24 \mathrm{~h}$.

pore volume. The $\mathrm{N}_{2}$ adsorption isotherms were analyzed using the Brunauer-Emmett-Teller (BET) equation, allowing us to obtain the specific surface area of the titanium oxide nanoparticles $\left(S_{\mathrm{BET}}\right)$. The results of calculation were indicated in Table 1 . When the $\left[\mathrm{NH}_{3}\right]$ values were $0.1 \mathrm{~mol} / \mathrm{L}$ and $1 \mathrm{~mol} / \mathrm{L}$, the $S_{\mathrm{BET}}$ values were, respectively, $358 \mathrm{~m}^{2} / \mathrm{g}$ and $445 \mathrm{~m}^{2} / \mathrm{g}$. With the higher concentration of $\mathrm{NH}_{3}$ (aq), coordination of $\mathrm{NH}_{3}$ molecules to $\mathrm{Ti}^{4+}$ ions inhibited rapid growth and aggregation of the nanoparticles so that higher specific surface area were achieved. However, the $S_{\mathrm{BET}}$ value of the anatase $\mathrm{TiO}_{2}$ particles obtained by heating the mixture of TIP and $\mathrm{H}_{2} \mathrm{O}$ was $214 \mathrm{~m}^{2} / \mathrm{g}$. Accordingly, the titanium oxide nanoparticles obtained using the reaction between the ethylene glycol solution of TIP and $\mathrm{NH}_{3}$ (aq) had quite large $S_{\text {BET }}$ values compared to those particles obtained using the conventional hydrolysis reaction of TIP. As, shown in the Table 1, the total pore volumes of the titanium oxide nanoparticles obtained with $0.1 \mathrm{~mol} / \mathrm{L}$ and $1 \mathrm{~mol} / \mathrm{L}$ of $\mathrm{NH}_{3}$ aqueous solutions were $0.12 \mathrm{~cm}^{3} / \mathrm{g}$ and $0.13 \mathrm{~cm}^{3} / \mathrm{g}$, respectively, and they had very close values. The average pore sizes of the nanoparticles obtained with the $0.1 \mathrm{~mol} / \mathrm{L}$ of $\mathrm{NH}_{3}$ (aq) were larger than those obtained with the $1 \mathrm{~mol} / \mathrm{L}$ of $\mathrm{NH}_{3}$ (aq). Both of the average pore sizes were smaller than $2 \mathrm{~nm}$ so that the nanoparticles obtained with $\mathrm{NH}_{3}$ (aq) were microporous materials. On the other hand, the average pore size of the anatase $\mathrm{TiO}_{2}$ particles obtained by heating the mixture of TIP and $\mathrm{H}_{2} \mathrm{O}$ was $4.67 \mathrm{~nm}$. Accordingly, the obtained anatase $\mathrm{TiO}_{2}$ was a mesoporous material. The dependence of the porosity and the pore size on the $\mathrm{NH}_{3}$ 
TABLE 1: The BET specific surface areas of the nanoparticles obtained by heating the mixture of the ethylene glycol solution of TIP and the $\mathrm{NH}_{3}$ aqueous solution. Average pore diameter and total pore volume were estimated by using the $\mathrm{BJH}$ method to the $\mathrm{N}_{2}$ adsorption isotherms shown in Figure 6.

\begin{tabular}{lccc}
\hline The solution added to ethyleneglycol solution of TIP & {$\left[\mathrm{NH}_{3}\right]=0.1 \mathrm{M}$} & {$\left[\mathrm{NH}_{3}\right]=1 \mathrm{M}$} & $\mathrm{H}_{2} \mathrm{O}$ \\
\hline$S_{\text {BET }}$ & $358 \mathrm{~m}^{2} / \mathrm{g}$ & $445 \mathrm{~m}^{2} / \mathrm{g}$ & $214 \mathrm{~m}^{2} / \mathrm{g}$ \\
Average pore diameter & $1.34 \mathrm{~nm}$ & $1.17 \mathrm{~nm}$ & $4.67 \mathrm{~nm}$ \\
Total pore volume & $0.12 \mathrm{~cm}^{3} / \mathrm{g}$ & $0.13 \mathrm{~cm}^{3} / \mathrm{g}$ & $0.25 \mathrm{~cm}^{3} / \mathrm{g}$ \\
\hline
\end{tabular}

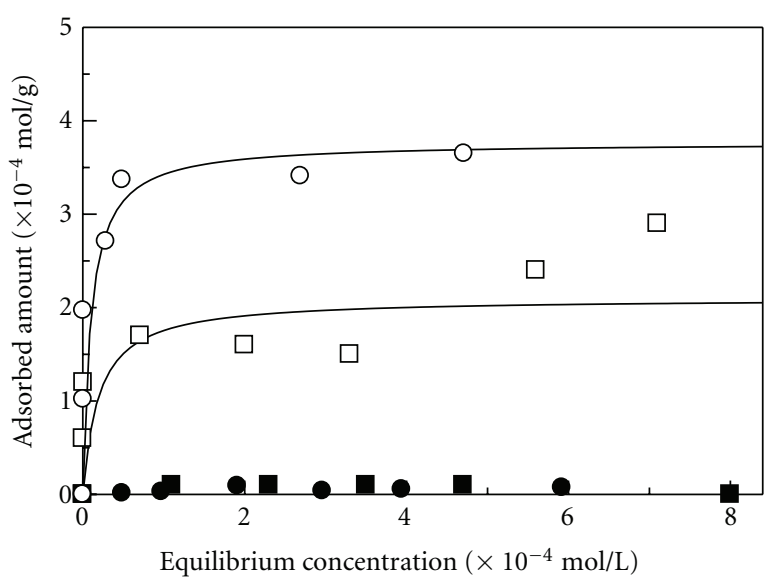

FIgURe 7: Adsorption isotherms of dye molecules on the titanium oxide nanoparticles in aqueous solution of dye. Aqueous solutions of the dye molecules were the following: $\bigcirc$, methylene blue; $\square$, crystal violet; $\boldsymbol{\bullet}$, Evans blue; $\mathbf{\square}$, eosin Y. The titanium oxide nanoparticles were prepared using the aqueous solution having $\left[\mathrm{NH}_{3}\right]$ of $1 \mathrm{~mol} / \mathrm{L}$.

(aq) concentration reflected the difference of the hydrolysis reaction in the solutions.

Adsorption isotherms of dye molecules were measured to investigate the interaction between the dye molecules and the titanium oxide nanoparticle surfaces. Figure 7 presents adsorption isotherms of dye molecules on the titanium oxide nanoparticles obtained at $\left[\mathrm{NH}_{3}\right]=1 \mathrm{~mol} / \mathrm{L}$. The adsorption isotherms of the cationic dye molecules of methylene blue and crystal violet on the obtained titanium oxide nanoparticles are shown, respectively, as open circles and open squares. The black line shows the result of least-square curve-fitting based on Langmuir equation, which fits the experimental data very well. The saturated adsorbed amount of methylene blue and crystal violet was, respectively, $3.59 \times$ $10^{-4} \mathrm{~mol} / \mathrm{g}$ and $2.02 \times 10^{-4} \mathrm{~mol} / \mathrm{g}$. The adsorption isotherms of the anionic dye molecules of eosin $\mathrm{Y}$ and Evans blue on the titanium oxide nanoparticles are shown, respectively, as closed squares and closed circles. The saturated adsorbed amounts of eosin $\mathrm{Y}$ and Evans blue, as calculated from the Langmuir plots, were, respectively, $8.25 \times 10^{-6} \mathrm{~mol} / \mathrm{g}$ and $6.91 \times 10^{-6} \mathrm{~mol} / \mathrm{g}$. Accordingly, the saturated adsorbed amounts of the anionic dye molecules were less than $1 / 50$ of those of the cationic dye molecules. Highly selective adsorption of the cationic dye molecules was observed.

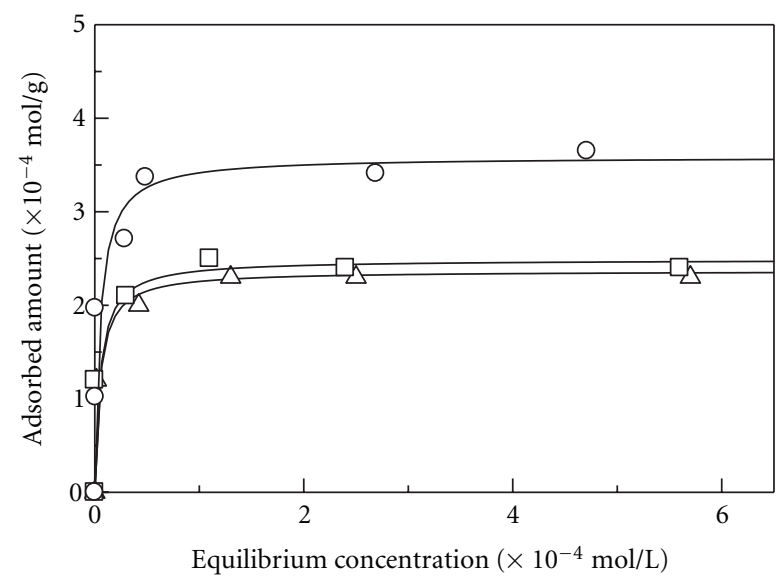

FIGURE 8: Adsorption isotherms of methylene blue on the titanium oxide nanoparticles in aqueous solution of dye. The $\mathrm{NH}_{3}$ aqueous solutions concentrations used to prepare the titanium oxide nanoparticles were the following: $\bigcirc, 1 \mathrm{~mol} / \mathrm{L} ; \square, 0.2 \mathrm{~mol} / \mathrm{L} ; \Delta$, $0.1 \mathrm{~mol} / \mathrm{L}$.

To examine more details of the selective adsorption of the cationic dye molecules, the adsorption isotherms of methylene blue, which is a cationic dye molecule, were measured as presented in Figure 8. The adsorbents were titanium oxide nanoparticles prepared by using $\mathrm{NH}_{3}(\mathrm{aq})$ whose concentrations were $0.1 \mathrm{~mol} / \mathrm{L}, 0.2 \mathrm{~mol} / \mathrm{L}$, and $1 \mathrm{~mol} / \mathrm{L}$. The saturated adsorbed amounts estimated by using the Langmuir plot were, respectively, $2.37 \times 10^{-4} \mathrm{~mol} / \mathrm{g}, 2.49 \times$ $10^{-4} \mathrm{~mol} / \mathrm{g}$, and $3.59 \times 10^{-4} \mathrm{~mol} / \mathrm{g}$. The saturated adsorbed amounts corresponded to $S_{\mathrm{BET}}$ values of the titanium oxide nanoparticles.

Figure 9 shows adsorption isotherms of Evans blue, which is an anionic dye molecule. The saturated adsorbed amounts of Evans blue molecules of the nanoparticles were less than $2.5 \times 10^{-5} \mathrm{~mol} / \mathrm{g}$. According to the results presented in Figures 8 and 9, the cationic dye molecules interacted strongly with the surface of the titanium oxide nanoparticles obtained by heating the mixtures of ethylene glycol solution of TIP and $\mathrm{NH}_{3}(\mathrm{aq})$. As presented in Figure 1(d), when the $\left[\mathrm{NH}_{3}\right]$ value was $1 \mathrm{~mol} / \mathrm{L}$, the obtained nanoparticles were mixture of anatase $\mathrm{TiO}_{2}$ and layered titanic acid. In general, a layered titanic acid structure shows the cationic ion exchange property. Therefore, an enhanced adsorption towards the cationic dye molecules on the nanoparticles 


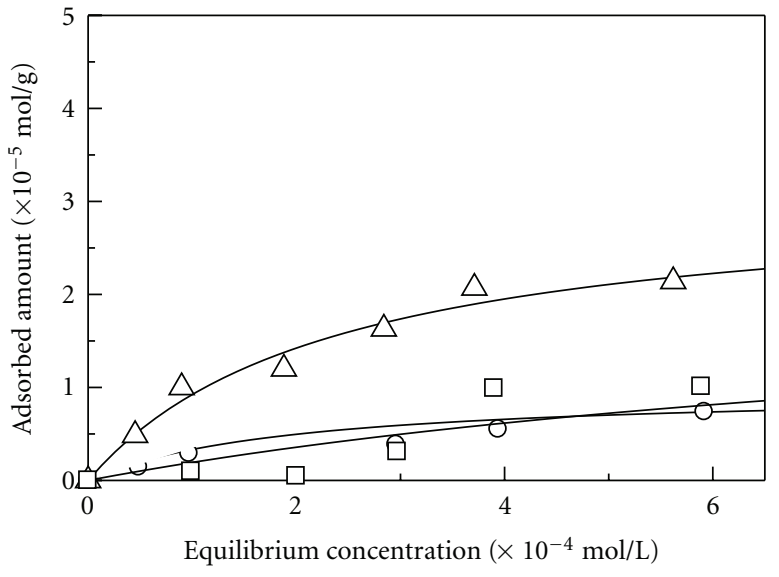

FIGURE 9: Adsorption isotherms of Evans blue on the titanium oxide nanoparticles in aqueous solution of dye. The concentrations of $\mathrm{NH}_{3}$ (aq) used to prepare the titanium oxide nanoparticles were the following: $\bigcirc, 1 \mathrm{~mol} / \mathrm{L} ; \square, 0.2 \mathrm{~mol} / \mathrm{L}$; and $\triangle, 0.1 \mathrm{~mol} / \mathrm{L}$.

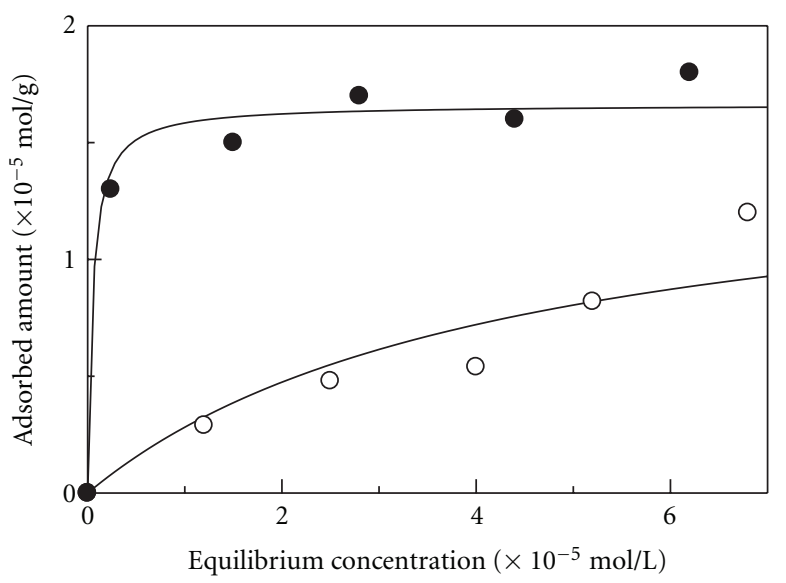

Figure 10: Adsorption isotherms of dye molecules on titanium oxide nanoparticles in aqueous solution of dye. The dye molecules were the following: $\bigcirc$, methylene blue and $\bullet$, Evans blue. Titanium oxide nanoparticles were prepared by heating the mixture of TIP and $\mathrm{H}_{2} \mathrm{O}$ at $368 \mathrm{~K}$ for $24 \mathrm{~h}$.

corresponded to the presence of layered titanic acid structure in the obtained nanoparticles. On the other hand, although the XRD peaks of the nanoparticles prepared at $\left[\mathrm{NH}_{3}\right]=$ $0.1 \mathrm{~mol} / \mathrm{L}$ as presented in Figure 1(a) can be assigned only to anatase $\mathrm{TiO}_{2}$, the obtained nanoparticles also showed the enhanced adsorption towards the cationic dye molecules. In this case, the layered titanic acid particles with very low degree of crystallization were included in the obtained nanoparticles so that the presence of the layered titanic acid phase cannot be detected by XRD. To examine the above consideration, the adsorption characteristics of conventional anatase $\mathrm{TiO}_{2}$ particles, the dye adsorption isotherms of the particles were presented in Figure 10. The saturated adsorbed amounts of methylene blue and Evans blue were, respectively, $1.50 \times 10^{-5} \mathrm{~mol} / \mathrm{g}$ and $1.66 \times 10^{-5} \mathrm{~mol} / \mathrm{g}$. In this case, the adsorbed amount of Evans blue, an anionic dye molecule, was larger than that of methylene blue, a cationic dye molecule. This adsorption behavior was opposite to the titanium nanoparticles obtained from the ethylene glycol solution of TIP and $\mathrm{NH}_{3}$ aqueous solution. Accordingly, the positively charged sites on the anatase particles such as $\mathrm{Ti}^{4+}$ ions played an important role in the adsorption of Evans blue molecules. Therefore, the adsorption behavior of the dye molecules depends strongly on the surface characteristics. Results show that the selective adsorption of the cationic dye molecules did not correspond to the anatase $\mathrm{TiO}_{2}$ structure. The layered titanic acid structure is expected to play an important role in the selective adsorption of the cationic dye molecules. The hydrolysis reaction with a sufficient amount of $\mathrm{NH}_{3}$ aqueous solution enabled formation of a composite of layered titanic acid structure and anatase $\mathrm{TiO}_{2}$, and it is considered that the structure contributed to the selective dye adsorption characteristics.

\section{Conclusion}

Transparent and stable sols of titanium oxide nanoparticles were obtained by heating a mixture of ethylene glycol solution of TIP and $\mathrm{NH}_{3}$ aqueous solution at $368 \mathrm{~K}$ for $24 \mathrm{~h}$. The concentration of $\mathrm{NH}_{3}$ aqueous solution affected the structure of the obtained titanium oxide nanoparticles. When the concentration of $\mathrm{NH}_{3}$ aqueous solution was $0.1 \mathrm{~mol} / \mathrm{L}$, the obtained nanoparticles were assigned to anatase $\mathrm{TiO}_{2}$ according to the XRD pattern. When the concentration was higher than $0.2 \mathrm{~mol} / \mathrm{L}$, a mixture of anatase $\mathrm{TiO}_{2}$ nanoparticles and layered titanic acid nanoparticles was obtained. The coordination of ethylene glycol and $\mathrm{NH}_{3}$ molecules to $\mathrm{Ti}^{4+}$ ions played an important role in the formation of titanium oxide nanoparticles and their homogeneous dispersion in the sol. The obtained titanium oxide nanoparticles had a large specific surface area, which was larger than $350 \mathrm{~m}^{2} / \mathrm{g}$ because the aggregation of their nanoparticles was prevented by the coordination of $\mathrm{NH}_{3}$ and ethylene glycol molecules. The obtained titanium oxide nanoparticles indicated an enhanced adsorption towards the cationic dye molecules. The selective adsorption corresponded to presence of the layered titanic acid on the nanoparticles. The high specific surface area also played an important role for the selective adsorption of the cationic dye molecules. Accordingly, the hydrolysis reaction of TIP with ethylene glycol and $\mathrm{NH}_{3}$ enabled us to obtain stable sols of anatase $\mathrm{TiO}_{2}$ and layered titanic acid nanoparticles with highly homogeneous dispersion. Furthermore, the obtained nanoparticles showed unique adsorption characteristics.

\section{Acknowledgment}

This work was supported by the Grant-in-Aid for Scientific Research (C) of the Japan Society for the Promotion of Science. 


\section{References}

[1] A. Alem, H. Sarpoolaky, and M. Keshmiri, "Titania ultrafiltration membrane: preparation, characterization and photocatalytic activity," Journal of the European Ceramic Society, vol. 29, no. 4, pp. 629-635, 2009.

[2] K. Lv, J. Yu, L. Cui, S. Chen, and M. Li, "Preparation of thermally stable anatase $\mathrm{TiO}_{2}$ photocatalyst from $\mathrm{TiOF}_{2}$ precursor and its photocatalytic activity," Journal of Alloys and Compounds, vol. 509, no. 13, pp. 4557-4562, 2011.

[3] C. Bechinger, S. Ferrere, A. Zaban, J. Sprague, and B. A. Gregg, "Photoelectrochromic windows and displays," Nature, vol. 383, no. 6601, pp. 608-610, 1996.

[4] E. Topoglidis, A. E. G. Cass, G. Gilardi, S. Sadeghi, N. Beaumont, and J. R. Durrant, "Protein adsorption on nanocrystalline $\mathrm{TiO}_{2}$ films: an immobilization strategy for bioanalytical devices," Analytical Chemistry, vol. 70, no. 23, pp. 5111-5113, 1998.

[5] M. R. Hoffmann, S. T. Martin, W. Choi, and D. W. Bahnemann, "Environmental applications of semiconductor photocatalysis," Chemical Reviews, vol. 95, no. 1, pp. 69-96, 1995.

[6] K. M. Lee, V. Suryanarayanan, J. H. Huang, K. R. J. Thomas, J. T. Lin, and K. C. Ho, "Enhancing the performance of dyesensitized solar cells based on an organic dye by incorporating $\mathrm{TiO}_{2}$ nanotube in a $\mathrm{TiO}_{2}$ nanoparticle film," Electrochimica Acta, vol. 54, no. 16, pp. 4123-4130, 2009.

[7] W. J. Tseng and K. C. Lin, "Rheology and colloidal structure of aqueous $\mathrm{TiO}_{2}$ nanoparticle suspensions," Materials Science and Engineering A, vol. 355, no. 1-2, pp. 186-192, 2003.

[8] U. G. Akpan and B. H. Hameed, "The advancements in solgel method of doped- $\mathrm{TiO}_{2}$ photocatalysts," Applied Catalysis $A$, vol. 375, no. 1, pp. 1-11, 2010.

[9] C. D. Jaeger and A. J. Bard, "Spin trapping and electron spin resonance detection of radical intermediates in the photodecomposition of water at $\mathrm{TiO} 2$ particulate systems," Journal of Physical Chemistry, vol. 83, no. 24, pp. 3146-3152, 1979.

[10] N. Sakai, R. Wang, A. Fujishima, T. Watanabe, and K. Hashimoto, "Effect of ultrasonic treatment on highly hydrophilic $\mathrm{TiO}_{2}$ surfaces," Langmuir, vol. 14, no. 20, pp. 5918-5920, 1998.

[11] B. O’Regan and M. Grätzel, "A low-cost, high-efficiency solar cell based on dye-sensitized colloidal $\mathrm{TiO}_{2}$ films," Nature, vol. 353, no. 6346, pp. 737-740, 1991.

[12] M. K. Nazeeruddin, A. Kay, I. Rodico et al., "Conversion of light to electricity by cis-X2bis $\left(2,2^{\prime}\right.$-bipyridyl-4,4' -dicarboxylate)ruthenium(II) charge-transfer sensitizers $\left(\mathrm{X}=\mathrm{Cl}^{-}, \mathrm{Br}^{-}\right.$, $\mathrm{I}^{-}, \mathrm{CN}^{-}$, and $\mathrm{SCN}^{-}$) on nanocrystalline titanium dioxide electrodes," Journal of the American Chemical Society, vol. 115, no. 14, pp. 6382-6390, 1993.

[13] M. C. Rath, D. K. Palit, T. Mukherjee, and H. N. Ghosh, "Sensitization of $\mathrm{TiO}_{2}$ nanoparticles in micro-emulsion by photoexcited dye molecules: a femtosecond transient absorption study," Journal of Photochemistry and Photobiology A, vol. 204, no. 2-3, pp. 209-216, 2009.

[14] M. I. Zaki, G. A. H. Mekhemer, N. E. Fouad, T. C. Jagadale, and S. B. Ogale, "Surface texture and specific adsorption sites of sol-gel synthesized anatase $\mathrm{TiO}_{2}$ nanoparticles," Materials Research Bulletin, vol. 45, no. 10, pp. 1470-1475, 2010.

[15] N. Nakayama and T. Hayashi, "Preparation of $\mathrm{TiO}_{2}$ nanoparticles surface-modified by both carboxylic acid and amine: dispersibility and stabilization in organic solvents," Colloids and Surfaces A, vol. 317, no. 1-3, pp. 543-550, 2008.

[16] N. Uekawa, M. Suzuki, T. Ohmiya, F. Mori, Y. J. Wu, and K. Kakegawa, "Synthesis of rutile and anatase $\mathrm{TiO}_{2}$ nanoparticles from Ti-peroxy compound aqueous solution with polyols," Journal of Materials Research, vol. 18, no. 4, pp. 797-803, 2003.

[17] A. Singh and R. C. Mehrotra, "Novel heterometallic alkoxide coordination systems of polyols (glycols, di- and tri-ethanolamines) derived from the corresponding homometallic moieties," Coordination Chemistry Reviews, vol. 248, no. 1-2, pp. 101-118, 2004.

[18] L. G. Hubert-Pfalzgraf, "Some aspects of homo and heterometallic alkoxides based on functional alcohols," Coordination Chemistry Reviews, vol. 178-180, no. 2, pp. 967-997, 1998.

[19] M. Zhang, Z. Jin, J. Zhang et al., "Effect of annealing temperature on morphology, structure and photocatalytic behavior of nanotubed $\mathrm{H}_{2} \mathrm{Ti}_{2} \mathrm{O}_{4}(\mathrm{OH})_{2}$," Journal of Molecular Catalysis A, vol. 217, no. 1-2, pp. 203-210, 2004.

[20] M. R. Harrison, P. P. Edwards, and J. B. Goodenough, "A study of the $\mathrm{Li}_{1+\mathrm{x}} \mathrm{Ti}_{2-\mathrm{x}} \mathrm{O}_{4}$ spinel system by diffuse-reflectance spectroscopy," Journal of Solid State Chemistry, vol. 54, no. 3, pp. 426-437, 1984.

[21] S. J. Gregg and K. S. W. Sing, Adsorption, Surface Area and Porosity, Academic Press, London, UK, 2nd edition, 1982. 

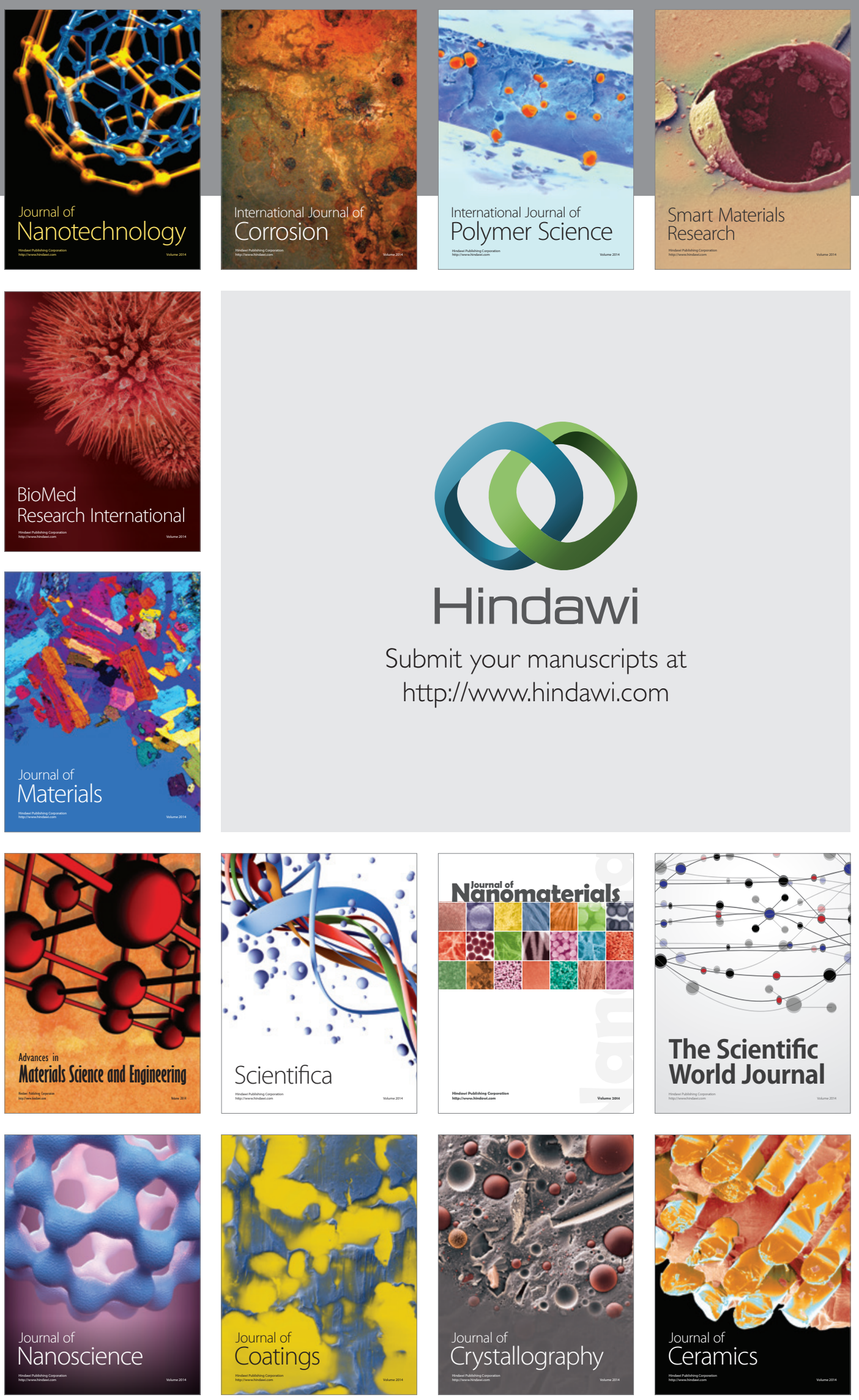

The Scientific World Journal

Submit your manuscripts at

http://www.hindawi.com

\section{World Journal}

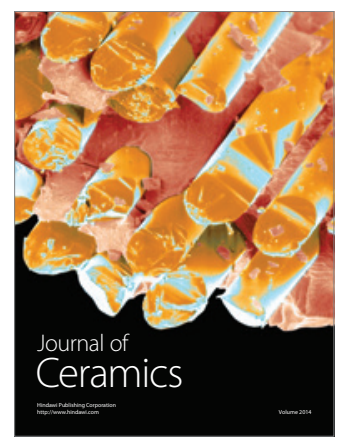

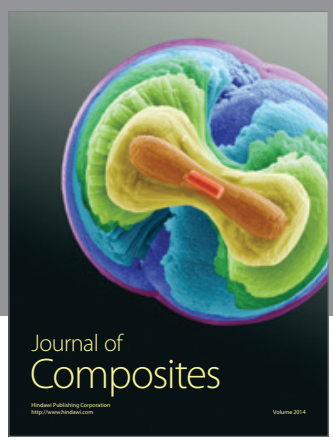
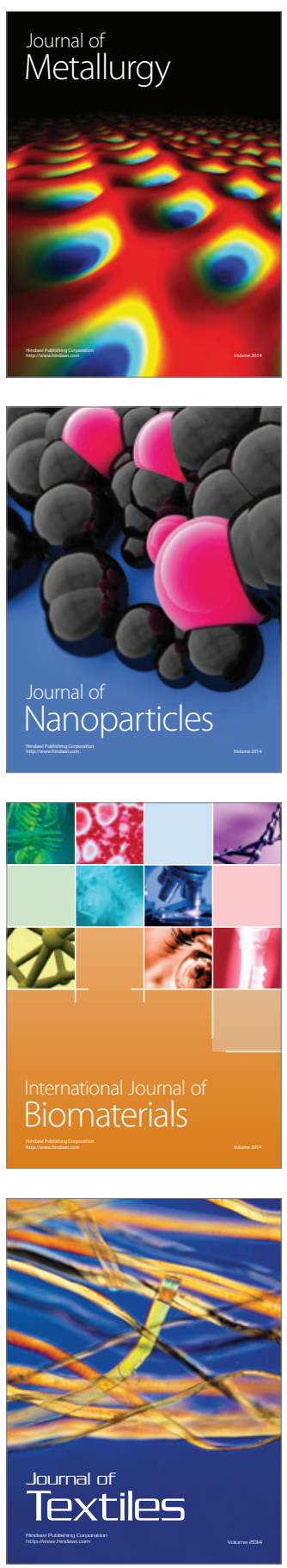